\title{
ESTIMATING AMBER DISEASE IN GRASS GRUB POPULATIONS BY VISUAL ASSESSMENT AND DNA COLONY BLOT ANALYSIS
}

\author{
T.A. JACKSON, R.J. TOWNSEND, T.L. NELSON, \\ N.K. RICHARDS and T.R. GLARE
}

\author{
AgResearch, PO Box 60, Lincoln
}

\begin{abstract}
Estimating levels of amber disease, caused by strains of the bacteria Serratia entomophila andS. proteamaculans, in populations of Costelytra zealandica is important for management of the pest. Since discovery of the disease, visual assessment has been the main method for disease estimation, but development of an amber disease specific DNA probe provides the opportunity to use bacterial colony blot analysis for detection of disease. Visual assessment and colony blot analysis of third instar grass grub populations produced similar estimates of disease and were highly correlated. The probe could also be used to determine the presence of disease causing bacteria in prepupal/pupal populations when visual disease symptoms were not evident.
\end{abstract}

Keywords: Grass grub, Costelytra zealandica, amber disease, Serratia spp., diagnostics, DNA probe.

\section{INTRODUCTION}

Amber disease is a bacterial disease of grass grub (Costelytra zealandica (White)) caused by strains of the bacteria Serratia entomophila and $S$. proteamaculans bearing a specific disease encoding plasmid, pADAP (Glare et al. 1993). The disease is recognised as a regulatory factor of grass grub populations (Jackson 1984; Jackson 1993) and strains of S. entomophila have been developed as the biological control product Invade (Jackson et al. 1992). Natural epizootics of amber disease are common among grass grub populations and sometimes occur at levels of up to $80 \%$ of larvae infected (Trought et al. 1982). Amber disease is a chronic disease of grass grub larvae and is characterised by cessation of feeding and gut clearance in the early stages of disease (Jacksonet al. 1993). However, in mature larvae it is often hard to differentiate between diseased and healthy larvae as accumulated fat obscures the gut. Also, some larvae display temporary amber symptoms unrelated to infection by Serratia spp. Thus, it is important to develop objective indicators of disease which can be used in prediction of grass grub population change. DNA technology provides such an alternative. A DNA probe has been developed which is specific to the disease causing plasmid (Glare et al. submitted). In this paper we compare bacterial colony blot analysis using the DNA probe with visual diagnosis for estimating the level of disease in grass grub populations.

\section{METHODS}

Grass grub larvae were field collected from pastures in Canterbury where the grass grub biological control product Invade had been applied. From each site, the larvae were categorised as diseased or healthy on the basis of visual symptoms of disease (Jackson et al. 1993). Each larva was then cut into two in the region of the anterior thoracic segments and gut fluid was streaked in a short band across a plate of caprylate thallous agar (CTA) (Starr et al. 1976) and incubated for 3 days at $30^{\circ} \mathrm{C}$. A plasmid-bearing and plasmid-free strain of S.entomophila were included on each CTA plate as the positive and negative controls respectively. The resultant bacterial colonies were then transferred onto Hybond-N membrane (Amersham, Life Science) as per the manufacturer's 
instructions. DNA was fixed to the membrane by UV cross-linking. Development of the probe, an $E c o \mathrm{R} 1$ segment of pADAP designated pMS20 is described elsewhere (Glare et al. submitted). ${ }^{32-P}$ DNA probes were prepared by randomin vitro labelling following the procedure of the rediprime DNA labelling system (Amersham, Life Science) and purified by passage through a sephadex G-50 column (Sambrook et al. 1989). All prehybridisation, hybridisation and washing steps were carried out in a Biometra(OV3) oven at $65^{\circ} \mathrm{C}$. Colony blots were prehybridised in $2 \mathrm{xSSC}(0.3 \mathrm{M} \mathrm{NaCl}, 30 \mathrm{mM}$ sodium citrate) for $15 \mathrm{mins}$, followed by prehybridisation buffer ( $1 \mathrm{mM} \mathrm{EDTA}, 0.5 \mathrm{M} \mathrm{Na}_{2} \mathrm{PO}_{4}$, $7 \% \mathrm{SDS})$ for $1-3 \mathrm{hrs}$. Twenty microlitres of denatured probe $\left(100^{\circ} \mathrm{C}, 5 \mathrm{mins}\right)$ were then added and the blots hybridised overnight. After three 15 minute washes in $2 x S S C$, the blots were exposed to X-ray film (Kodak, X-OMAT AR) overnight. Following developing, the autoradiographs were visually scored using the positive and negative controls as references.

In a further test, late instar larvae and pupae were taken from four untreated grass grub populations in Canterbury and processed as outlined above. In addition to the gut smear, $10 \mu \mathrm{l}$ of whole insect macerate, produced by blending with $1 \mathrm{ml}$ sterile deionised water with a Ultra-turrax T25 blender at 15000 revs for 7 seconds, was inoculated onto the CTA medium.

Results were analysed using chi-squared test for independence and the McNemer Change test corrected for continuity (Siegel and Castellan 1988).

\section{RESULTS}

Both methods produced a similar overall estimate of disease (Table 1). Of the 409 larvae examined, visual examination categorised $35 \%$ of larvae as diseased, while the use of the specific DNA probe produced $37 \%$ positive bacterial colonies. In each of the samples the correlation between methods was highly significant $(\mathrm{P}<0.001)$ using the chisquare test, although there were a considerable number of samples which produced contradictory test results. For example, Sample 1 produced a significantly greater $(\mathrm{P}<0.01 \mathrm{McNemer}$ test), number of colonies that probed positive among apparently healthy larvae than would be expected while Sample 3 produced a greater number $(\mathrm{P}<0.01)$ of colonies probing negative among visually diseased larvae than expected.

TABLE 1: Amber disease assessment from grass grub larvae using visual assessment and colony blot analysis of bacterial colonies isolated from larvae.

\begin{tabular}{|c|c|c|c|c|c|c|c|}
\hline \multirow[t]{2}{*}{ Sample } & \multirow[t]{2}{*}{$\begin{array}{l}\text { Collection } \\
\text { time }\end{array}$} & \multicolumn{2}{|c|}{$\begin{array}{l}\text { Diseased } \\
\text { visual } \\
\text { assessment }\end{array}$} & \multicolumn{2}{|c|}{$\begin{array}{l}\text { Healthy } \\
\text { visual } \\
\text { assessment }\end{array}$} & \multirow{2}{*}{$\begin{array}{c}\text { Chi } \\
\text { square } \\
\text { test } \\
X^{2}\end{array}$} & \multirow{2}{*}{$\begin{array}{c}\text { McNemer } \\
\text { Change } \\
\text { Test } \\
X^{2}\end{array}$} \\
\hline & & Probe+ & Probe- & Probe+ & Probe- & & \\
\hline 1 & July 1995 & 45 & 5 & 19 & 31 & $31.6 * * *$ & $7.0 * *$ \\
\hline 2 & May 1996 & 33 & 10 & 16 & 83 & $51.4 * * *$ & $1.0 \mathrm{~ns}$ \\
\hline 3 & June 1996 & 23 & 13 & 2 & 70 & $19.5 * * *$ & $6.6 * *$ \\
\hline 4 & June 1996 & 11 & 3 & 3 & 42 & $26.7 * * *$ & $0.2 \mathrm{~ns}$ \\
\hline \multirow{2}{*}{\multicolumn{2}{|c|}{$\begin{array}{l}\text { Total larvae } \\
\% \text { in each category }\end{array}$}} & 112 & 31 & 40 & 226 & & \\
\hline & & 27 & 8 & 10 & 55 & & \\
\hline
\end{tabular}

Grass grub collected from the October 1996 sampling were mostly in the pupal and prepupal stage with a small number of retarded larvae showing symptoms of disease. Probing, however, revealed that $17-50 \%$ of insects were carrying the disease causing bacteria with greater numbers of bacterial colonies with homology to the probe detected from the macerates than the smears (Table 2).

TABLE 2: Detection of amber disease causing bacteria among prepupal and pupal grass grub populations sampled in October $1996(P$, pupae; $L$, 
larvae) by visual assessment and DNA probe of isolated bacterial colonies.

\begin{tabular}{llccc}
\hline Site & $\mathrm{n}$ & $\begin{array}{c}\text { Visual } \\
\text { disease } \\
(\mathrm{A})\end{array}$ & $\begin{array}{c}\text { Colony probe+ } \\
\text { smears } \\
(\mathrm{B})\end{array}$ & $\begin{array}{c}\text { Colony probe+ } \\
\text { macerates } \\
(\mathrm{C})\end{array}$ \\
\hline Murdoch & $17(15 \mathrm{P}, 2 \mathrm{~L})$ & 1 & 6 & 9 \\
Willis & $10(6 \mathrm{P}, 4 \mathrm{~L})$ & 0 & 5 & 5 \\
Porter & $20(19 \mathrm{P}, 1 \mathrm{~L})$ & 0 & 4 & 4 \\
WIRS & $12(5 \mathrm{P}, 7 \mathrm{~L})$ & 3 & 2 & 4 \\
Total & 59 & 4 & 17 & 22 \\
McNemer $X^{2}$ & & & $\mathrm{~A}$ vs B $=9.6^{* *}$ & $\mathrm{~B}$ vs C $=1.5 \mathrm{~ns}$ \\
\hline
\end{tabular}

\section{DISCUSSION}

Amber disease symptoms, gut clearance and cessation of feeding, are clearly associated with infection by disease-causing strains of Serratia spp. (Stucki et al.1984; Jacksonet al. 1993) but accurate visual assessment of the level of disease in a population is difficult. In the tests described in this paper, both visual analysis and DNA dot blot methods produced similar estimates of disease in feeding larvae but each method had its strengths and weaknesses. Visual assessment has been used most frequently to date and is rapid and relatively low cost. The weakness of visual assessment is that amber symptoms are occasionally produced from other causes (which could be the case with Sample 3), and the estimate of disease will vary depending on the experience of the observer. Isolation of bacteria from individual larvae for confirmation of disease is possible, but agar plate based identification is a laborious process (Stucki et al 1984; O'Callaghan and Jackson 1993a). It is also impossible to tell, from the visual symptoms of disease, whether larvae are infected once they have reached the fatty stage of the mid third instar. The DNA probe pMS20, on the other hand, has homology to a fragment of the disease causing plasmid, pADAP and hence will only detect disease causing bacteria. In combination with theSerratia spp. selective medium, CTA, the probe gives consistent results but it is more time consuming and hence more expensive than visual examination. If, however, there are high numbers of non pathogenic bacteria in the insects these can outgrow the pathogenic strain on the CTA agar and the latter will remain undetected. This is an alternative explanation for the discrepancy between larvae showing disease symptoms and positive probes in Sample 3.

The greatest advantage of the DNA probe is that it allows detection of disease causing bacteria in insect stages where disease symptoms are not apparent. This may have been the reason for the high number of positive probed colonies from apparently healthy larvae in Sample 1. In the October sample, disease was only apparent among the few remaining larvae, but probing revealed that $20-50 \%$ of grass grubs were carrying the bacteria. The effects of bacteria on pupae are not known, but adult beetles have been implicated as important factors in the transport and distribution of pathogenic strains of bacteria (O’Callaghan and Jackson 1993b).

In summary, both methods of estimation of amber disease have strengths and weaknesses. Visual assessment is adequate where a quick result is required for disease estimates among early third instar larvae. The DNA probe is more appropriate for confirmation of ambiguous visual results, for assessments at the pupal and adult stages and also as a technique which can be used for detection of bacteria in all life stages for experimental studies to determine ecology of bacteria and epizootiology of disease.

\section{ACKNOWLEDGEMENTS}

We thank Dave Saville for statistical advice

\section{REFERENCES}

Glare, T.R., Corbett, G.E. and Sadler, A.J., 1993. Association of a large plasmid with amber disease of the New Zealand grass grub, Costelytra zealandica, caused by 
Serratia entomophila and S. proteamaculans. J. Invert. Path. 62: 165-170.

Glare, T.R., Inwood, A., Hurst, M.R.H., Nelson, T.L., Townsend, R.J. and Jackson, T.A., (submitted). Detection of amber disease-causing Serratia spp. from the host using plasmid-specific DNA probes.Molecular Ecol.

Jackson, T.A., 1984. Honey disease, an indicator of population decline in grass grub. Proc. 37th N.Z. Weed and Pest Control Conf.: 113-116.

Jackson, T.A., 1993. Advances in the microbial control of pasture pests in New Zealand. Proc. 6th Aust. Grassl. Invert. Ecol. Conf.: 304-311.

Jackson, T.A., Pearson, J.F., O'Callaghan, M., Mahanty, H.K. and Willocks, M. 1992. Pathogen to product-development ofSerratia entomophila (Enterobacteriacae) as a commercial biological control agent for the New Zealand grass grub (Costelytra zealandica). Pp. 191-198 In: Use of Pathogens in Scarab Pest Management. T.A. Jackson and T.R. Glare (Eds.). Intercept, Andover, UK.

Jackson, T.A., Huger, A.M. and Glare T.R. 1993. Pathology of amber disease in the New Zealand grass grub Costelytra zealandica (Coleoptera:Scarabaeidae). J. Invert. Path. 61: 123-130.

O'Callaghan, M. and Jackson, T.A., 1993a. Isolation and enumeration of Serratia entomophila - a bacterial pathogen of the New Zealand grass grub, Costelytra zealandica. J. Appl. Bacteriol. 75: 307-314.

O'Callaghan, M. and Jackson, T.A., 1993b. Adult grass grub dispersal of Serratia entomophila. Proc. 46th N.Z. Plant Prot. Conf.: 235-236.

Sambrook, J., Frisch, E.F. and Maniatis, T., 1989. Molecular Cloning. A Laboratory Manual. 2ndEdn. Cold Spring Harbour Laboratory Press, USA, pp 859.

Siegel, S. and Castellan, N.J., 1988. Nonparametric Statistics for Behavioural Sciences, 2ndEdn. McGraw-Hill, New York, pp 399.

Starr, M.P., Grimont, P.A.D., Grimont, F. and Starr, P.B., 1976. Caprylate thallous agar medium for selectively isolating Serratia and its utility in the clinical laboratory.J. Clin. Microbiol. 4: 270-276.

Stucki, G., Jackson, T.A. and Noonan, M.J., 1984. Isolation and characterisation of Serratia strains pathogenic for larvae of the New Zealand grass grub Costelytra zealandica. N.Z. J. Sci. 27: 255-260.

Trought, T.E.T., Jackson, T.A. and French, R.A., 1982. Incidence and transmission of a disease of grass grub (Costelytra zealandica) in Canterbury. N.Z. J. Exp. Agric. 10: 79-82. 